Molecules 2001, 6, M247

\title{
4-Formylphenyl 4-Ferrocenylbenzoate
}

\section{Ke-Qing Zhao, Ping Hu and Hong-Bo Xu}

Department of Chemistry, Sichuan Normal University, Chengdu, 610066, China

Tel./Fax: 86-28-4764743. Email: zkq2@yahoo.com (Present e-mail: zhao@hrz2.hrz.tu-darmstadt.de)

Received: 28 May 2001 / Accepted: 14 December 2001 / Published: 20 December 2001

Keywords: liquid crystal, non-linear optical material, metallomesogen, ferrocene, 4-ferrocenylbenzoic acid, 4-hydroxybenzaldehyde, esterification reaction, 4-formylphenyl 4-ferrocenylbenzoate, ester
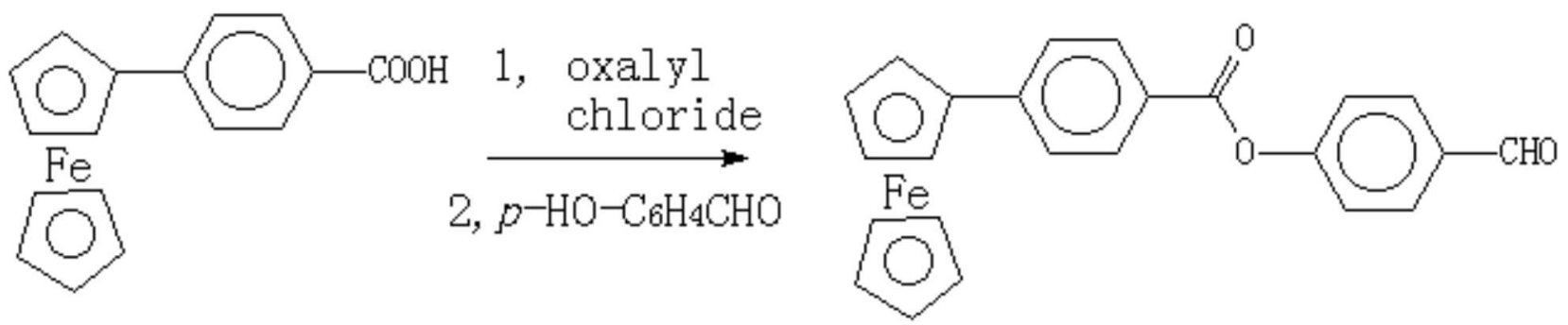

Ferrocene unit is comparatively large volume and it needs a longer molecular shape in geometry in to support the liquid crystal property [1]. 4-Formylphenyl 4-ferrocenylbenzoate contains a formyl group and can further condenses with amine, so it is a key intermediate for the synthesis of ester-Schiff's base ferocene-containg liquid crystal material. Following is the synthetic procedure. 4-Ferrocenylbenzoic acid [2] $(9.6 \mathrm{~g}, 30 \mathrm{mmol})$ is dissolved in $150 \mathrm{ml}$ of $\mathrm{CHCl}_{3}$ and $7.5 \mathrm{ml}$ oxalyl chloride is added. The mixture is refluxed $24 \mathrm{~h}$ with stirring under protection of $\mathrm{CaCl}_{2}$ dry tube. The mixture is concentrated in vacuum. The residue is extracted with $180 \mathrm{ml}$ of petroleum ether (boiling range $90-120^{\circ} \mathrm{C}$ ) three times under refluxing. After cooling, the extracts give product as solid. The product is filtered and dried in vacuum to give 4-ferrocenylbenzoylchloride $\left(8.2 \mathrm{~g}, 80 \%\right.$ in yield, m.p. $\left.134-135^{\circ} \mathrm{C}\right)$ and it can be used for next step without further purification. The mixture of 4-hydroxybenzaldehyde( $3.1 \mathrm{~g}, 25 \mathrm{mmol})$, 4-ferrocenylbenzoyl chloride $(8.2 \mathrm{~g}, 25 \mathrm{mmol})$ and $2 \mathrm{ml}$ pyridine in $100 \mathrm{ml}$ benzene is refluxed $10 \mathrm{~h}$ under the protection of a $\mathrm{CaCl}_{2}$ drying tube until the disappearance of acid chloride as monitored by thin-layer chromatography. After reaction has finished, the clear upper layer is decanted from the oily lower layer. After cooling, the product is collected by filtration to give 4-formylphenyl 4-ferrocenylbenzoate $(8.0 \mathrm{~g}$, yield $78 \%)$.

M.p.: $195-196^{\circ} \mathrm{C}$.

$\operatorname{IR}\left(\mathrm{KBr}, \mathrm{cm}^{-1}\right): 1720,1693,1272$.

${ }^{1} \mathrm{HNMR}\left(\mathrm{CDCl}_{3}, 200 \mathrm{MHz}\right):$ 10.04(1H, S, CHO), 7.57-8.13(4H, dd, J=8.26Hz, ArCHO), 7.41-8.01(4H, $\mathrm{dd}, \mathrm{J}=8.38 \mathrm{~Hz}, \mathrm{Fc}-\mathrm{Ar}), 4.46-4.78\left(4 \mathrm{H}, \mathrm{d}, \mathrm{C}_{5} \mathrm{H}_{4}\right), 4.08\left(5 \mathrm{H}, \mathrm{S}, \mathrm{C}_{5} \mathrm{H}_{5}\right)$.

Elemental analysis for $\mathrm{C}_{24} \mathrm{H}_{18} \mathrm{FeO}_{3}$ : calculated, $\mathrm{C}, 69.73 ; \mathrm{H}, 4.36 \%$. Found: $\mathrm{C}, 69.55 ; \mathrm{H}, 4.52 \%$.

\section{Reference}

1. Collinson, S.; Bruce, D. W. Metallomesogen-- supramolecular organization of metal complexes in fluid phases, in: Transition Metals in Supramolecular Chemistry, edit. by Jean-Pierre Sauvage, John Wiley \& Sons; 1999, pp285.

2. Zhao, Ke-Qing; Hu, Ping and Xu, Hong-Bo. 4-Ferrocenylbenzoic Acid. Molecules 2001, 6, M246.

Sample Availability: Available from the authors and from MDPI. 
(C) 2001 MDPI. All rights reserved. Molecules website http://www.mdpi.org/molecules/ 